\title{
Accounting Regulation and Financial Reporting Quality: Pre-and-Post IFRS Nigeria Evidence
}

\author{
Philip Jehu*1 and Mohammad Azhar Ibrahim ${ }^{2}$ \\ ${ }^{1}$ Federal University Kashere, Gombe, Nigeria \\ 2 Tunku Puteri Intan Safinaz School of Accountancy, Universiti Utara Malaysia
}

\begin{abstract}
The purpose of this study is to examine whether accounting regulation is associated with financial reporting quality in Nigeria. Using accrual-based earnings management construct - abnormal accruals as a proxy for financial reporting quality, the study found some significant variation in abnormal accruals with the implementation of International financial reporting standards (IFRS) to regulate accounting practice. Similarly, the research found that the control variables - firm size, leverage, and return on asset have significant effects on financial reporting quality. This study is found to be consistent with previous studies indicating the effectiveness of IFRS adoption in improving financial reporting quality. The study also contributes to the discussion on IFRS adoption across reporting environments. Regulatory agencies in Nigeria might need to consider the combined effect of other corporate governance laws to ensure quality reporting. The study is limited by our sample (2009 - 2014), and by the proxies for both accounting regulation and financial reporting quality, the data of which was in most part handpicked. Future research might consider testing the combined effect of other corporate governance variables like audit committees and board characteristics.
\end{abstract}

Keywords: Financial Reporting Quality, Accounting Regulation, IFRS, Abnormal Accruals, Developing Country

JEL Classification: G38, M41, M48

Paper Type: Research 


\section{INTRODUCTION}

The quality of financial reporting has been an issue of concern to regulators, standard setters, policymakers, and shareholders alike. This situation has shaken investor's confidence in financial reporting and corporate governance on several instances to date. These upheavals have led to chain reaction across regulatory borders, with the enactment of laws and regulations that influence corporate financial reporting (Filip, Labelle, \& Rousseau, 2015). There is empirical evidence that supports the view that IAS/IFRS adoption enhances the quality of financial reporting, which increases its relevance to investors. The main aim of IFRS adoption is to see improvement in accounting quality. Palea (2013) concluded that accounting regulation is a critical factor that determines financial reporting quality (FRQ). In contrast, Ahmed, Neel, and Wang (2013) found evidence of a decline in accounting quality after IFRS adoption.

Motivated by IFRS adoption in 2012 and the series of recent regulatory initiatives and corporate governance codes, and the study of Abdulmalik and Ahmad (2016), this paper examines (1) accounting regulation is associated with $F R Q,(2)$ there is shift in this relationship for the years following IFRS, and (3) overall, FRQ declined following IFRS. ${ }^{1}$ We employ the accrual-based earnings management construct - abnormal accruals to proxy for FRQ, we found some variation in abnormal accruals with the adoption of IFRS, to regulate accounting.

The Financial Reporting Council (FRC) of Nigeria passed a regulation which requires all publicly listed firms to adopt IFRS, starting from January 2012. This regulation is expected to cause a paradigm shift in the business environment because before 2012; firms followed local generally accepted accounting principles (GAAP). To provide insight into how this expected change had progressed, the study reviews the literature on IFRS adoption and their effects on reporting quality. Thereafter, the study provides empirical evidence on these changes for the pre- and post-IFRS periods. Accordingly, the need to further investigate the extent to which accounting regulation affects FRQ (Palea, 2013) remains a subject of debate and investigation in different regulatory environments. This is so because, over the years, progress has been made in some areas of the corporate information setting, notably the disclosure regulation consequences and the economic outcome of financial reporting decisions (Beyer, Cohen, Lys, \& Walther, 2010).

To the best of the authors' knowledge, there is only one study, that is Abdulmalik and Che-Ahmad (2016) that examines the effects of regulatory change on financial reporting quality in Nigeria for a relatively large sample of firms. Similarly, this study differs from Abdulmalik and Che-Ahmad (2016) in three areas. First, the research focuses on IFRS implementation which proxy for accounting regulation, whereas their regulatory change is concerned with the contemporaneous corporate governance code. Second, the paper shows that abnormal accruals are more positive for IFRS firms for the post-adoption period. However, their findings of a decrease in absolute discretionary accruals and abnormal audit fees might be essentially driven by clients who pay abnormally higher audit fees, which does not necessarily suggest a decrease in earnings management. Third, the study adopted and applied the test for Cramer's z-statistics which gives additional insights.

The purpose of this study is to examine (1) accounting regulation is associated with financial reporting quality, (2) this relationship changed for the years following IFRS, and (3) overall, financial reporting quality declined following IFRS. The authors employed accrual-based earnings management construct - abnormal accruals as a proxy for financial reporting quality, and found some variation in abnormal accruals with the

\footnotetext{
1 Our accruals-based earnings management construct is abnormal accruals measured by the Kothari et al (2005) performanceadjusted model. The model is appropriate to this study for its specificity on current earnings as generated by prior year assets.
} 
implementation of IFRS to regulate accounting. The study contributes to the debate IFRS adoption for a quality financial reporting. Regulatory bodies might find this research useful to consolidate on implementation specificity of IFRS provisions.

This paper is organised into five sections. The next following introduction section, Section 2 presents a literature review and hypothesis development. Section 3 discusses the research design while Section 4 presents empirical results based on the analysis. The last section, Section 5 concludes this paper.

\section{LITERATURE REVIEW}

Most accounting and corporate governance research have focused majorly on corporate board characteristics, audit committee attributes, and auditors as the mechanisms for enhancing financial reporting quality. Accounting regulation provides the platform on which corporate financial reporting thrives. Therefore, the role that regulatory agencies and their lawmaker's allies play to determine financial reporting outcome cannot be overemphasised.

\subsection{Financial Reporting Quality}

A higher quality financial reporting with the corresponding higher disclosure requirement that follows IFRS adoption can potentially mitigate managerial incentive for accruals earnings management (latridis, 2010). Objectivity would lead to less opportunism to influence reported earnings which is misleading to investors. Thus, in reporting environments with robust investor protection mechanisms, like the UK and the EU, IFRS adoption costs would likely be lower. This is true since earnings management level is lower because managers have less chance to manipulate accounting earnings (Dayanandan et al., 2016; Palea, 2013; Soderstrom \& Sun, 2007). In contrast, jurisdictions with weak investor protection rights have higher scope earnings management, and thus lowering the quality of financial reporting, which implies a higher IFRS adoption costs.

The financial reporting quality hypotheses in this study examine whether IFRS adoption (a proxy for accounting regulation) enhances or diminishes earnings management in Nigeria (see Abdulmalik \& Ahmad, 2016; Leuz, Nanda, \& Wysocki, 2003). Following Abbott, Daugherty, Parker, and Peters (2016), we employed the Kothari, Leone, and Wasley (2005) performance-matched measure of abnormal accruals as a proxy for financial reporting quality. The model was developed to report current earnings as generated by the value of lagged assets. This can easily be manipulated by opportunistic managers.

\subsection{Accounting Regulation}

Akisik (2013) document that accounting regulation has continued to be the epicentre of an enduring debate in the accounting field, with the debate coming to the limelight following several dramatic financial reporting scandals and frauds in the early 2000s. This event together with several recent scandals did diminish public confidence in capital markets. These accounting scandals that erupted in the USA caused several upheavals. First, Enron's fall stupefied the world (Di Pietra, McLeay, \& Ronen, 2010). An appalling unfolding series of accounting irregularities in other large US corporations followed, and this spread into Europe, Asia, Australia, and Africa. Nigeria has its fair share of the fraud in Cadbury and several other listed firms. 
These upheavals caused the lawmakers to act in the form of regulatory reforms around the world. There is Sarbanes-Oxley Act (SOX) in the US, and numerous corporate governance codes around the world followed. Nigeria joined other countries to adopt the IFRS - financial institutions in 2009, and non-financial firms in 2012 . So, "the institutions of accounting regulation continue to change with the increasing worldwide adoption of IFRS" (Wagenhofer, 2011).

The increasing need to improve on the quality of financial statements prompt regulators to standardise and increase coverage of the explanatory and narrative aspects of annual reports and accounts (Di Pietra, Gebhardt, McLeay, \& Ronen, 2014). This can be observed by the increase in some pages and volume of annual reports occasioned by forward-looking items that may not necessarily improve FRQ (Ewert \& Wagenhofer, 2015). The quest for more effective regulation is closely linked to corporate governance laws requires sufficient dynamism to provide for the complexities of the changing firms' characteristics.

\section{THEORETICAL FRAMEWORK AND HYPOTHESES DEVELOPMENT}

Extant literature suggests that accounting regulation improves financial reporting quality (Abdulmalik \& Ahmad, 2016; Ewert \& Wagenhofer, 2015; Inchausti, 1997; Jones \& Sharma, 2001; Wagenhofer, 2011). Palea (2013) examined whether IFRS affect FRQ. Her empirical evidence supported the view that IFRS adoption enhances FRQ, which is beneficial to the investors. Even though empirical findings indicate arguments in support of an improved reporting quality under IFRS, yet there are grounds to suggest mandatory adoption per se does not suffice to improve FRQ. Some other factors in country's legal system and political environment provide incentives in the financial reporting process.

Jones and Sharma (2001) examined the impact of financial leverage, free cash flow, and accounting regulation on earnings management. They found that the stringent disclosure regulation imposed by the Australian Stock Exchange was responsible for the variation in the levels of effect free cash flow and financial leverage has on earnings management. While the negative sign of the leverage variable indicates a counter-intuitive premise that lower leverage is related to higher earnings management. On the other hand, the sign of the free cash flow turned mixed, which indicates that free cash flow levels are not associated with earnings management.

According to the agency theory, managerial opportunistic behaviour potentially influences accounting earnings in their favour regarding bonuses and substantial executive compensations following a favourable performance evaluation. This provides a pretext for conflict of interests as this opportunistic behaviour affect the quality of financial reports perused by the investors. The theory, therefore, provides an avenue to understanding the influence of accounting standards such as IFRS on the managers' opportunistic behaviour, that borders on several forms of earnings management (Dayanandan et al., 2016). Dayanandan et al. (2016) found empirical evidence that presupposes IFRS adoption leads to a decline in earnings management where high-level financial disclosure requirements exist.

Meanwhile, IFRS adoption, (i.e. accounting regulation) affect FRQ which cause convergence in financial reporting (Palea, 2013). Moreover, this relationship often changes in the years following a regulatory initiative and intervention, for example, SOX (Cohen, Dey, \& Lys, 2008; Ghosh, Marra, \& Moon, 2010). The findings on the association between these variables continue to be inconsistent (latridis, 2010; Lin \& Hwang, 2010).

Based on the preceding argument, the authors hypothesised that: 
$\mathrm{H}_{1}$ : There is a positive relationship between accounting regulation and financial reporting quality.

$\mathrm{H}_{2}$ : There is a change in the relationship between accounting regulation and financial reporting quality in the years following IFRS.

\section{RESEARCH DESIGN}

\subsection{Sample}

This study is based on listed non-financial firms that were directed to implement IFRS in Nigeria, beginning from January 2012. The research covers 2009 to 2014 time-periods, inclusive. The study used 200 firms listed on the floor of the Nigerian Stock Exchange, from which samples were collected. We came out with a final sample of 96 firms having dropped the financial firms as well as those firms that did not have complete information. The financial firms have a separate regulatory body that encouraged them to adopt IFRS from 2009. Corporate governance data were hand-collected from the annual reports downloaded from the NSE website. We also obtained financial data from Thomson Reuters EIKON database.

The critical financial parameter employed was financial reporting quality proxied by abnormal accruals. We analysed it using the performance-adjusted Kothari et al. (2005) model to detect accruals earnings management. We examined the nexus between accounting regulation and $F R Q$ using a panel regression.

\subsection{Regression Model}

To test the nexus between accounting regulation and financial reporting quality in the preand post- IFRS evidence, the authors adapt a regression model from previous research as follows:

$A B N A C C_{i t}=\beta_{0 i t}+\beta_{1} A_{R E G}+\beta_{2} F_{\text {FIZE }}$ it $+\beta_{3}$ ROA $_{i t}+\beta_{4} \mathrm{LEV}_{\text {it }}+\beta_{5} \mathrm{LSTAGE}_{\text {it }}+\beta_{6} \mathrm{BIG}_{\text {it }}$ YEAR_D + INDUSTRY_D $+\varepsilon_{\text {it }}$

The variables employed in the empirical model are presented in Table 1.

Table 1. Variables definition and measurements

\begin{tabular}{|c|c|c|c|}
\hline Variable & Variable Label & Measurement & Source \\
\hline ABNACC & Abnormal accruals & $\begin{array}{l}\text { Abnormal accruals from the } \\
\text { performance-matched cross-sectional } \\
\text { model of Kothari et al. (2005) }\end{array}$ & $\begin{array}{l}\text { Abbott et al. (2016); } \\
\text { Abdulmalik and Ahmad } \\
(2016)\end{array}$ \\
\hline AREG & $\begin{array}{l}\text { Accounting regulation } \\
\text { (Financial reporting } \\
\text { system) }\end{array}$ & $\begin{array}{l}\text { A dummy variable assumes a value of } 1 \\
\text { for the post-IFRS period and a value of } 0 \\
\text { for the pre-IFRS period }\end{array}$ & $\begin{array}{l}\text { Dayanandan et al. } \\
\text { (2016); } \\
\text { latridis (2010) }\end{array}$ \\
\hline FSIZE & Firm size & Log of total assets & $\begin{array}{l}\text { Bonetti et al (2016); } \\
\text { Inchausti (1997) }\end{array}$ \\
\hline ROA & Return on assets & Net income/total assets & $\begin{array}{l}\text { Bonetti et al (2016); } \\
\text { Inchausti (1997) }\end{array}$ \\
\hline LEV & Leverage & Total liabilities/total assets & $\begin{array}{l}\text { Bonetti et al (2016); } \\
\text { Inchausti (1997) }\end{array}$ \\
\hline LSTAGE & Listing age & Log of listing age & $\begin{array}{l}\text { Archambeault, Dezoort, } \\
\text { and Hermanson (2008) }\end{array}$ \\
\hline BIG4 & BIG4 firms & $\begin{array}{l}\text { A dummy variable is } 1 \text { if a firm is BIG4, } \\
\text { and } 0 \text { otherwise }\end{array}$ & $\begin{array}{l}\text { Abdulmalik and Ahmad } \\
\text { (2016); Inchausti } \\
\text { (1997) }\end{array}$ \\
\hline
\end{tabular}

Note: $A B N A C C=$ abnormal accruals, $A R E G=$ accounting regulation, FSIZE $=$ firm size, $L E V=$ leverage, $R O A=$ return on assets, LSTAGE = listing age, BIG4 = big4 firms. 


\subsection{Dependent Variable}

Following prior literature (Abbott et al., 2016; Kothari et al., 2005), our measure of financial reporting quality is obtained from the performance-matched Jones model. We compute abnormal accruals as the residuals of error-term from the following regression:

$$
T A_{i t} / A_{i t-1}=\beta_{0}+\beta_{1}\left(1 / A_{i t-1}\right)+\beta_{2}\left(\left(\Delta R E V_{i t}-\Delta A R_{i t}\right) / A_{i t-1}\right)+\beta_{3}\left(P P E_{i t} / A_{i t-1}\right)+\beta_{4}\left(N P_{i t} / A_{i t-1}\right)+\varepsilon_{i t}
$$

Where; Total accruals $\left(T A_{i t}\right)$ for firm $i$ for year $t$ is computed as the difference between net profit (that is, income before extraordinary items) and the operating cash flows. $A_{i t}$ is the total assets. $\triangle R E V_{i t}$ is the change in revenue. $\triangle A R_{i t}$ is the change in account receivables. $P P E_{i t}$ is the gross value of plant, property, and equipment. $N P_{i t}$ is the net profit. $\varepsilon_{i t}$ is the error term. $\beta_{0}$ is the intercept. $\beta_{1}$ to $\beta_{4}$ are the coefficients of independent variables.

\section{EMPIRICAL RESULTS}

This study mainly examines whether accounting regulation is associated with financial reporting quality. We employ accrual-based earnings management construct - abnormal accruals as a proxy for financial reporting quality. We include control variables - firm size, leverage, return on asset, and big4 firms (which include Ernst \& Young, PricewaterhouseCoopers, Deloitte, and KPMG) to run our regression analysis.

\subsection{Descriptive Statistics}

Table 2 reports the descriptive statistics for all the variables used in this study. The mean, standard deviation and median of abnormal accruals (ABNACC) are $0.723,0.380$, and 0.722 respectively. On the average accounting regulation has about $69 \%$ compliance with IFRS, with a standard deviation of 0.46. the skewness and kurtosis are 0.80 and 1.64 respectively. For the control variables, firm size shows an average of 7.04 with a standard deviation of 0.70 . The firms are moderately leveraged at $57 \%$ with a standard deviation of $20 \%$. The average return on asset is somewhat on the low side, $4 \%$. The firms are quite old with a median listing age of 21. Most of the firms have BIG4 firms as their auditors, with an average of $55 \%$.

Table 2. Descriptive Statistics

\begin{tabular}{|c|c|c|c|c|c|c|c|}
\hline Variable & Min & Max & Mean & $\begin{array}{l}\text { Standard } \\
\text { Deviation }\end{array}$ & Median & Skewness & Kurtosis \\
\hline ABNACC & .1437216 & 1.339746 & .7228415 & .3803767 & .7222148 & .0444415 & 1.846009 \\
\hline AREG & 0 & 1 & .6857639 & .4646144 & 1 & -.800 & 548 \\
\hline FSIZE & 5.85474 & 8.140601 & 7.0 & .7000177 & 7.009895 & .01223 & 038 \\
\hline LEV & .2509715 & .9265614 & .5731638 & .2006032 & .5611996 & .1053861 & 2.049793 \\
\hline ROA & -.1187917 & .1788974 & .0440603 & .0836001 & .0466465 & -.2752401 & 2.535552 \\
\hline LSTAGE & 0 & 59 & 20.63715 & 13.58126 & 21 & .2263493 & 2.005380 \\
\hline BIG4 & 0 & 1 & 5520833 & .4977122 & 1 & -.2094729 & 1.043879 \\
\hline
\end{tabular}

Note: $A B N A C C=$ abnormal accruals, AREG $=$ accounting regulation, FSIZE $=$ firm size, LEV $=$ leverage, ROA $=$ return on assets, LSTAGE $=$ listing age, BIG4 = big4 firms.

\subsection{Correlation Matrix}

Table 3 presents the correlation coefficients of the variables. A look at the table indicates that there is no multicollinearity. The highest correlation between and among the explanatory variables is 0.5936 . Accounting regulation has positive and significant 
correlations with firm size, listing age, and Big4, but a negative nexus with abnormal accruals as expected. Abnormal accruals have a significant negative association with firm size. This translates to the bigger the size of the firm, the more the abnormal accruals declines.

Table 3. Pairwise correlation

\begin{tabular}{|c|c|c|c|c|c|c|c|}
\hline & ABNACC & AREG & LFSIZE & LEV & ROA & LSTAGE & BIG4 \\
\hline ABNACC & 1.0000 & & & & & & \\
\hline AREG & -0.0779 & 1.0000 & & & & & \\
\hline FSIZE & $-0.1149 *$ & $0.1963^{*}$ & 1.0000 & & & & \\
\hline LEV & 0.0727 & 0.0569 & $0.1246^{*}$ & 1.0000 & & & \\
\hline ROA & 0.0744 & -0.0628 & $0.1769^{*}$ & $-0.3266^{*}$ & 1.0000 & & \\
\hline LSTAGE & $0.1372^{*}$ & $0.1023^{*}$ & -0.0743 & $0.1751^{*}$ & $0.1373^{*}$ & 1.0000 & \\
\hline BIG4 & -0.0019 & $0.5936^{*}$ & 0.0396 & 0.0177 & -0.0461 & $0.1056^{*}$ & 1.0000 \\
\hline
\end{tabular}

Note: Significance at $5 \%$ level denoted as ${ }^{*}$. ABNACC $=$ abnormal accruals, AREG $=$ accounting regulation, FSIZE $=$ firm size, LEV = leverage, ROA = return on assets, LSTAGE = listing age, BIG4 = big4 firms.

\subsection{Abnormal Accruals around IFRS}

As the primary objective of IFRS is to provide a high-quality financial reporting and information that is understandable and usable by investors and other stakeholders, we examine whether the adoption of IFRS affects the financial reporting quality of sample firms. Table 4 presents the standard deviation, mean and median of our abnormal accruals measure both for the pre-and post-IFRS periods. The results show that the abnormal accruals measures for the post-IFRS period are lower than the pre-SOX numbers. The mean absolute abnormal accruals declined from 0.753 to 0.717 over the periods, with a mean difference of 0.036 , statistically significant at $1 \%$. We obtained a similar result for return on assets. Also, the study examined whether the disparity in the accounting regulation measure differs between the pre-and post-IFRS years. The authors found a decline in the standard deviation of accounting regulation from 0.493 to 0.200 for the preand post-IFRS years. Hence, there was a decline of 0.293 in the variation of accounting regulation following the passage of IFRS.

Table 4. Descriptive statistics for abnormal accruals surrounding IFRS

\begin{tabular}{llllllllll}
\hline & \multicolumn{3}{c}{ Pre-IFRS } & \multicolumn{3}{c}{ Post-IFRS } & \multicolumn{3}{c}{ Difference } \\
\cline { 2 - 10 } & Stdev & Mean & Median & Stdev & Mean & Median & Stdev & Mean & Median \\
\hline ABNACC & 0.410 & 0.753 & 0.742 & 0.444 & 0.717 & 0.710 & -0.034 & $0.036^{* * *}$ & $0.032^{* * *}$ \\
AREG & 0.493 & 0.413 & 0.000 & 0.200 & 0.958 & 1.000 & 0.293 & -0.545 & -1.000 \\
ROA & 0.138 & 0.057 & 0.058 & 0.158 & 0.025 & 0.038 & -0.020 & $0.032^{* * *}$ & $0.020^{* * *}$ \\
\hline
\end{tabular}

Note: This table shows the standard deviation, mean, and median of abnormal accruals surrounding IFRS. Abnormal accruals are taken as the absolute value of the abnormal discretionary accrual measure for matched-performance. AREG is accounting regulation, proxy by IFRS. ROA is a return on asset. We separate our sample into the pre-IFRS (2009 to 2011) and post-IFRS (2012 to 2014 ) periods. Significance at $1 \%, 5 \%$ and $10 \%$ levels are denoted as ${ }^{* \star *},{ }^{* *},{ }^{*}$ respectively, for a one-tailed test.

Overall, the results indicate that abnormal accruals earnings management reduced significantly following the adoption of IFRS, and the values gravitate to cluster round about the mean in excess of what they were during the pre-IFRS years. Accordingly, financial reporting quality improved following the implementation of IFRS.

\subsection{Diagnostic Tests}

Table 5 reports the summary of the diagnostic tests conducted. The continuous variables were all winsorised at $8 \%$ for outliers removal. We carried out the Hausman test to compare the random effect and fixed effect models, and the random effect turned better because the $p$-value obtained is 0.6997 which is greater than 0.10 . Indeed, the skewness 
and kurtosis values on Table 2 above shows that the data are all normal. The highest kurtosis obtained is 2.53 while the highest skewness is 0.105 . The Breusch-Pagan test (0.2020) indicated no heteroscedasticity, hence fulfilling the homoscedasticity requirement. We detected no multicollinearity as the mean-variance inflation factor (VIF) of 1.34 is $<2.0$, as recommended by Hair, Black, Babin, and Anderson (2014). The highest value is AREG having 1.64, and the least is LSTAGE having 1.13. The Wald test value of 26.07, having a statistical significance at 0.0005 indicates the model fitness. However, the Wooldridge test $(0.0509)$ showed that there is serial correlation problem. So, the study employed the xtregar command in Stata to solve the problem. Similarly, the authors carried out a robustness test for the random effects to solve both the heteroscedasticity as well as the serial correlation problem. We obtained a p-value of 0.0005 and a Wald value of 23.08, which is similar to the result obtained for the random effect.

Table 5. Diagnostic tests

\begin{tabular}{lcc}
\hline Tests & $\mathbf{X}^{\mathbf{2}}$ & $\mathbf{P}$ \\
\hline Breusch-Pagan test & 1.63 & 0.2020 \\
Wald & 26.07 & 0.0005 \\
Wooldridge test & 3.911 & 0.0509 \\
VIF & & 1.34 \\
\hline Source: Diagnostic output from Stata software
\end{tabular}

\subsection{Regression Results}

Table 6 shows our results based on the sample examined, whether or not the accounting regulation affects financial reporting quality. Our results provide evidence that accounting regulation has a negative statistical significant effect on financial reporting quality, for all the regressions carried out. The results of the pooled OLS, fixed effect and random effect are significant at $5 \%$, while the robustness test is significant at $10 \%$.

This study is run based on random effect. The coefficient of accounting regulation (AREG) on Table 6 indicates that there is a reduction in abnormal accruals by 0.0595 for each additional unit of AREG. The result suggests that accounting regulation exerts preference for IFRS to local GAAP which discourage accrual-based earnings management.

Consistent with prior literature (Abdulmalik \& Che-Ahmad, 2016; Dayanandan et al., 2016; Iatridis, 2010; Palea, 2013), we document that accounting regulation significantly reduces abnormal discretionary accruals which in turn improves financial reporting quality. The remaining results are control variables. They depict the inability of accounting regulation to significantly affect $F R Q$ on a stand-alone basis.

Table 6. Regression results

\begin{tabular}{lllll}
\hline Variables & Pooled OLS & Random Effects & Robust re & Fixed Effects \\
\hline AREG & $-0.0595^{* *}$ & $-0.0595^{* *}$ & $-0.0595^{*}$ & $-0.0667^{* *}$ \\
& $(0.0301)$ & $(0.0301)$ & $(0.0358)$ & $(0.0323)$ \\
FSIZE & $-0.0778^{*}$ & $-0.0778^{*}$ & -0.0778 & -0.122 \\
& $(0.0442)$ & $(0.0442)$ & $(0.0487)$ & $(0.115)$ \\
LEV & $0.167^{*}$ & $0.167^{*}$ & 0.167 & 0.125 \\
& $(0.0930)$ & $(0.0930)$ & $(0.124)$ & $(0.105)$ \\
ROA & $0.829^{* * *}$ & $0.829^{* * *}$ & $0.829^{* * *}$ & $0.938^{* * *}$ \\
& $(0.196)$ & $(0.196)$ & $(0.238)$ & $(0.212)$ \\
LSTAGE & $0.142^{*}$ & $0.142^{*}$ & $0.142^{* *}$ & $0.331^{* *}$ \\
& $(0.0777)$ & $(0.0777)$ & $(0.0672)$ & $(0.154)$ \\
BIG4 & 0.0393 & 0.0393 & 0.0393 & 0.0301 \\
& $(0.0359)$ & $(0.0359)$ & $(0.0365)$ & $(0.0369)$ \\
Constant & $0.978^{* * *}$ & $0.978^{* * *}$ & $0.978^{* * *}$ & 1.102 \\
& $(0.324)$ & $(0.324)$ & $(0.346)$ & $(0.804)$ \\
\hline
\end{tabular}




\begin{tabular}{lllll}
\hline Observations & 576 & 576 & 576 & 576 \\
R-squared & 0.053 & 0.053 & 0.056 & 0.056 \\
Number of firms & 96 & 96 & 96 & 96 \\
\hline Note: Standard errors in parentheses ${ }^{* * *}$ & $p<0.01,{ }^{* *} p<0.05,{ }^{*} p<0.1$. ABNACC = abnormal accruals, AREG \\
$=$ accounting regulation, FSIZE $=$ firm size, LEV = leverage, ROA = return on assets, LSTAGE = listing age, \\
BIG4 = big4 firms.
\end{tabular}

\subsection{Robustness Test}

We carried out a robustness test to solve the problem of heteroscedasticity and serial correlation on our random effect model. The results show the coefficient of accounting regulation (AREG) has a p-value of 0.043 which is negative and significant at $5 \%$ level. The result is consistent with all the tests we conducted.

\subsection{Pre- and Post-IFRS Additional Test}

Consistent with Tsalavoutas, André, and Evans (2012), we carried out the Cramer's Zstatistics test to see whether the relationship between accounting regulation and financial reporting quality changed for the years following IFRS. The within R-squared for the preIFRS is 0.026 while that of the post-IFRS is 0.083 . The result indicates a Z-score of -1.67 . Therefore, from our standard normal distribution table, we obtained the value 0.04746 which is significant at $5 \%$ level. This suggests that there is a significant variation in the quality of financial reporting for the years following IFRS adoption.

\section{CONCLUSION}

Fundamentally motivated by the series of regulatory initiatives, including IFRS adoption beginning 2012, and the recent work of Abdulmalik and Ahmad (2016), we examine whether (1) accounting regulation is associated with financial reporting quality, (2) this relationship changed over the years following IFRS, and (3) overall, financial reporting quality declined following IFRS. Using accrual-based earnings management construct abnormal accruals as a proxy for financial reporting quality, we found some variation in abnormal accruals with the implementation of IFRS to regulate accounting.

The result of this study is consistent with Abdulmalik and Ahmad (2016) indicating that a regulatory change improves the financial reporting process. Although employed as control variables, we found that firm size, leverage, and return on asset have significant effects on financial reporting quality. The return on asset is particularly, significant at $1 \%$, which show its nexus with the performance-matched Kothari model.

Overall, our evidence suggests that accounting regulation is successfully preventing corporate accrual earnings management, thereby improving financial reporting quality for the post-IFRS period. Hence, consistent with the conclusion by Dayanandan et al. (2016), IFRS adoption is effective in improving financial reporting quality. Nevertheless, because our study is univariate, our results may not provide acumen on the general effectiveness of IFRS.

Our research contributes to the discussion on IFRS adoption across reporting environments. The global convergence on IFRS is yet on-going with some countries retaining their local GAAP. Regulatory agencies in Nigeria might need to consider the combined effect of other corporate governance laws to ensure quality reporting. Our study is limited by our proxies for both accounting regulation and financial reporting quality, the data of which was in most part handpicked. Further studies might consider testing the combined effect of other corporate governance variables like audit committees and board characteristics. 


\section{REFERENCES}

Abbott, L. J., Daugherty, B., Parker, S., \& Peters, G. F. (2016). Internal audit quality and financial reporting quality: The joint importance of independence and competence. Journal of Accounting Research, 54(1), 3-40. http://doi.org/10.1111/1475-679X.12099

Abdulmalik, S., \& Ahmad, A. C. (2016). Audit fees, corporate governance mechanisms and financial reporting quality in Nigeria. DLSU Business \& Economics Review, 26(1), 122-135.

Ahmed, A. S., Neel, M., \& Wang, D. (2013). Does mandatory adoption of IFRS improve accounting quality? Preliminary evidence. Contemporary Accounting Research, 30(4), 1344-1372. http://doi.org/10.1111/j.1911-3846.2012.01193.x

Akisik, O. (2014). Accounting regulation, financial development, and economic growth. Emerging Markets Finance and Trade, 49(1), 33-67. http://doi.org/10.2753/REE1540-496X490103

Archambeault, D. S., Dezoort, F. T., \& Hermanson, D. R. (2008). Audit committee incentive compensation and accounting restatements. Contemporary Accounting Research, 25(4), 965-992. http://doi.org/10.1506/car.25.4.1

Beyer, A., Cohen, D. a., Lys, T. Z., \& Walther, B. R. (2010). The financial reporting environment: Review of the recent literature. Journal of Accounting and Economics, 50(2-3), 296-343. http://doi.org/10.1016/j.jacceco.2010.10.003

Bonetti, P., Magnan, M. L., \& Parbonetti, A. (2016). The influence of country- and firm-level governance on financial reporting quality: revisiting the evidence. Journal of Business Finance and Accounting, 43(9-10), 1059-1094. http://doi.org/10.1111/jbfa.12220

Cohen, D., Dey, A., \& Lys, T. (2008). Real and accrual-based earnings management in the preand post-Sarbanes Oxley periods. The Accounting Review, 83(3), 757-787.

Dayanandan, A., Donker, H., Ivanof, M., \& Karahan, G. (2016). IFRS and accounting quality: Legal origin, regional, and disclosure impacts. International Journal of Accounting and Information Management, 24(3), 296-316. http://doi.org/10.1108/IJAIM-11-2015-0075

Di Pietra, R., Gebhardt, G., McLeay, S., \& Ronen, J. (2014). Special issue in governance and accounting regulation. Journal of Management \& Governance, 18(3), 675-681. http://doi.org/10.1007/s10997-012-9238-1

Di Pietra, R., McLeay, S., \& Ronen, J. (2010). Special issue on governance and accounting regulation. Journal of Management \& Governance, 14(4), 273-276. http://doi.org/10.1007/s10997-009-9100-2

Ewert, R., \& Wagenhofer, A. (2015). Why more forward-looking accounting standards can reduce financial reporting quality. European Accounting Review, (June), 487-513. http://doi.org/10.1080/09638180.2015.1043927

Filip, A., Labelle, R., \& Rousseau, S. (2015). Legal regime and financial reporting quality. Contemporary Accounting Research, 32(1), 280-307. http://doi.org/10.1111/19113846.12071

Ghosh, A., Marra, A., \& Moon, D. (2010). Corporate boards, audit committees, and earnings management: Pre- and Post-SOX evidence. Journal of Business Finance and Accounting, 37(9-10), 1145-1176. http://doi.org/10.1111/j.1468-5957.2010.02218.x

Hair, J. F., Black, W. C., Babin, B. J., \& Anderson, R. E. (2014). Multivariate data analysis. Vectors (7th ed.). Harlow: Pearson Education Limited. http://doi.org/10.1016/j.ijpharm.2011.02.019

latridis, G. (2010). International financial reporting standards and the quality of financial statement information. International Review of Financial Analysis, 19(3), 193-204. http://doi.org/10.1016/j.irfa.2010.02.004

Inchausti, B. G. (1997). The influence of company characteristics and accounting regulation on information disclosed by Spanish firms. European Accounting Review, 6(1), 45-68. http://doi.org/10.1080/096381897336863

Jones, S., \& Sharma, R. (2001). The impact of free cash flow, financial leverage and accounting regulation on earnings management in Australia's "old" and "new" economies. Managerial Finance, 27(12), 18-39. http://doi.org/10.1108/03074350110767420

Kothari, S. P., Leone, A. J., \& Wasley, C. E. (2005). Performance matched discretionary accrual measures. Journal of Accounting and Economics, 39(1), 163-197. http://doi.org/https://doi.org/10.1016/j.jacceco.2004.11.002

Leuz, C., Nanda, D., \& Wysocki, P. D. (2003). Earnings management and investor protection: An 
international comparison. Journal of Financial Economics, 69(3), 505-527. http://doi.org/10.1016/S0304-405X(03)00121-1

Lin, J. W., \& Hwang, M. I. (2010). Audit quality, corporate governance, and earnings management: A meta-analysis. International Journal of Auditing, 14(1), 57-77. http://doi.org/10.1111/j.10991123.2009.00403.x

Palea, V. (2013). IAS/IFRS and financial reporting quality: Lessons from the European experience. China Journal of Accounting Research, 6(4), 247-263. http://doi.org/10.1016/j.cjar.2013.08.003

Soderstrom, N. S., \& Sun, K. J. (2007). IFRS adoption and accounting quality: A review. European Accounting Review, 16(4), 675-702. http://doi.org/10.1080/09638180701706732

Tsalavoutas, I., André, P., \& Evans, L. (2012). The transition to IFRS and the value relevance of financial statements in Greece. The British Accounting Review, 44(4), 262-277. http://doi.org/https://doi.org/10.1016/j.bar.2012.09.004

Wagenhofer, A. (2011). Towards a theory of accounting regulation: A discussion of the politics of disclosure regulation along the economic cycle. Journal of Accounting and Economics, 52(23), 228-234. http://doi.org/10.1016/j.jacceco.2011.08.006 